\title{
The Effect of Applying Holistic Mathematics Education (HME) Model Based on "Among System" Toward Character Values of Low-Grades Students
}

\author{
1: $1^{\text {st }}$ Rahmatul Hayati \\ Dept. of Mathematics \\ Universitas Dharmas Indonesia \\ Dharmasraya, Indonesia \\ rahmatulwahyu341@gmail.com \\ 1: $4^{\text {th }}$ Afriva Khaidir \\ Dept. Science of State Administration \\ Universitas Negeri Padang \\ Padang, Indonesia \\ af.khaidir@gmail.com
}

\author{
1: $2^{\text {nd }}$ Ahmad Fauzan \\ Dept. of Mathematics \\ Universitas Negeri Padang \\ Padang, Indonesia \\ ahmad.zan66@gmail.com
}

\author{
1: $3^{\text {rd }}$ Mega Iswari \\ Dept. of Non Formal Education \\ Universitas Negeri Padang \\ Padang, Indonesia \\ mega_iswari@yahoo.com
}

\begin{abstract}
This research aimed at developing holistic mathematics education (HME) model based on "among system" at low grades. This research focused to explore the effect of applying HME model towards students' character values. This research was a designed research followed by quasi experiment, which was done in elementary school on grade-III students (low grades) in Indonesia. Type of this research was a quasi experimental design, while the planning design was the Randomized Pretest-Posttest Only Control Group Design. Samples used in this research were students of grade III consisting of two classes chosen randomly after satisfying the requirement of analysis testing. One class was chosen as an experiment class, while another class was pointed as a control class. The instrument of this research was questionnaire of character values. The data was analyzed quantitatively by using Wilcoxon and Mann Whitney testing. The result of this research showed that: 1) there was an improvement of students' character values before and after giving treatments, thus it can be said that there was an influence of HME model based on "among system" towards character values of low-grades's students; 2) students' character values through HME model based on "among system" had significant changes compared to that taught by conventional model.
\end{abstract}

Keywords-Character Values, Holistic Mathematics Education (HME), Students' Low Grades.

\section{INTRODUCTION}

Character becomes very important to be developed in Indonesian society today because based on some study results, one's success is determined by the quality of its character $80 \%$ and only $20 \%$ is determined by its academic ability [1]. However, based on the existing reality, Indonesia is experiencing a multidimensional crisis where unemployment is high enough, poverty becomes a daily scene, moral depravity infects all elements of society, high rates of corruption, social unrest, juvenile delinquency, threat of global competition in the front eyes, and so forth. All these problems boil down to the fragility of the nation's character; therefore they must be addressed immediately. One solution to overcome these problems is through education.

Good education is not just a transfer of knowledge, but also to create a person who has a positive attitude and personality so as to form Human Resources (HR) quality and character. Mahatma Ghandi and Theodore Roosevelt [2] state that the success of the state can only be achieved by the moral citizens who do not give priority to the intelligence of the brain, but rather the quality of character.

One of the compulsory subjects that can make a significant contribution to the future of the nation, especially in the intellectual life of the nation and the growth of character values is mathematics. Mathematics as a science has characteristics, namely: (1) having abstract objects; (2) resting on agreement; (3) deductive mindset; (4) having empty symbols of meaning; (5) paying attention to the universe of speech; and (6) consistent in the system [3]. Within the characteristics of mathematics itself are actually embedded values that can build the character of students, including responsible, creative, innovative, productive, thinking, and consistent (obedient principle). For that reason, students' mathematical thinking skills need to be developed from the beginning they know the formal mathematics (primary school level) to the next level. Thus, students can reason, analyze facts, spark and organize ideas, defend opinions, make comparisons, draw conclusions, evaluate arguments, as well as solving problems in mathematics.

Other research also mentions that motivation and interests, as well as the development of character values are very influential on student learning achievement [4]-[8]. [4], [9]-[12] also explains that value education can deepen teacher and student relationships, make learning more effective, and create an effective learning environment. Character education given at the elementary school level has a long-term positive effect on students' lives [8]. Thus, it is important to develop the characters values through 
mathematics learning at the beginning of the school so that it will bring positive impact on the next stage, because mathematics and other academic lessons as a vehicle of education can not only be used to achieve a goal, such as educating students, but also can form a personality students [13]. Based on its characteristics, the early grades prefer to see things holistically. Some researchs (Bennett and Kaga, 2010; Khoo, 2010; Wall et al. 2015) suggested by [14] also mention that high-quality education for the early grades not only develop non potential academic course, but also develop the academic potential of students in order to form the ability of students for the next stage. Therefore, it is important to teach mathematics holistically so that students' potential will develop throughly, which impacts on the formation of student character values.

Many learning models can be used in learning mathematics, such as: realistic mathematics approach; problem based learning; cooperative learning; and contextual learning approach. Among these models, only a realistic mathematical approach is devoted to mathematics learning. Soedjadi mentions that other learning models are still general [15]. Some models have not provide yet the development of mathematics learning holistically in which child's potency will be developed physically, emotionally, socially, aesthetically, spritually, and intelectually, which impacts on the appearance of students' character values. Furthermore, the absence of mathematics learning model devoted to elementary school students is low, because at that stage concepts's undertsanding of the students as well as the planting of their character values need to be developed. Therefore, this study develops a model that can develop the potential of children holistically, namely HME model based "among system".

In developing the model, there are five basic components of the learning model [16], namely 1) Model syntax, which is a model stage developed [17], [18]; 2) The social system that explains how the role and relationship of teachers with students during the learning process; 3) The principle of reaction that explains the role of teachers as a tutor who places the students according to the stages of development of low-grade elementary school as the concept of the "among system" ; 4) Supporting system that describes all facilities that can support the HME model based on the "among system" low-grade elementary students; 5) The intructional impact of the impact of accompanist. The instructional impact of the model is the development of students 'character values, while the impact of accompanist is that this model can develop students' potential as a whole, ie intellectual, social, emotional, psychomotor, aesthetic and spiritual potential. Both instructional and accompanist impact are the focus of exposure in this paper.

Considering the importance of the teacher's role in learning, the Holistic Mathematics Education (HME) model based on " among system " is an effective model to improve the quality of mathematics learning in low classes. The HME model based on the intermediate system rests on the concept of holistic education which is an educational concept that develops all potential students in harmony, including intellectual, emotional, psychomotor, social, aesthetic, and spiritual potential [19]-[23]. Through the concept of holistic education, mathematics learning can help students develop their full potential in a meaningful learning environment through experience in interacting with their environment, because teaching holistically can help students who have diversity to be successful, and can make learning more effective [11], [24]. Based on the "system of among" which is the educational concept of Ki Hajar Dewantara (Minister of Education of Indonesia Era Soekarno), the teacher as a tutor can educate children on the basis of independence and freedom so that students can grow according to nature [25]. "Among systems" educates students by: 1) giving independence to students, 2) keeping children from pressing and forcing learning methods, and 3) instilling the nature of independence which is very important to make students more courageous in learning [26], as well as guiding children with full love and prioritizing the interests of children, so that children can develop according to their nature [27].The foundation of the "among system" lies in the motto "Tutwuri Handayani" which means giving freedom, opportunity, attention and guidance that enables the child or the younger generation on their own initiative and on their own experiences to develop according to their personal line [27]. This educational system is also found in Finland which has the best education system in the world. In Finland, all students are also given equal opportunities in education and remove barriers to learning, especially for students who are not successful in learning [28]. This became the main policy in the education system at Finland. In Finland, teachers are also responsible for their students as well as the concept of the intermediate system offered by Ki Hadjar Dewantara [29]. In the education syste, teachers help students to understand their lives so that students believe that everything can be achieved. The findings of some research also mention that Ki Hajar Dewantara's educational concept is a comprehensive education system, and one of lifelong educational system, and positions education as a guide [30]-[32]. Jean-Jacques Rousseau, an eighteenth-century philosopher whose ideas influence early childhood education, also suggests that learning must be linked to the interests of the child and that education should pay attention to the child's life. Rousseau also recommends that children are allowed to learn through self-initiated activities [33]. It also conforms to the HME model concept based on "amongst systems".

The HME model based on "among system" on lowgrade-elementary-school students has 10 stages that must be applied in learning so that students' potentials can thrive holistically [17], [18]. To apply the ten syntaxes of the model, the teacher needs to develop the supporting components of the model in accordance with the concept of "among system" so that the model applied in the learning can develop students' potentials thoroughly [17], [18]. The components of the model are: 1) Constructivism; 2) Natural Nature; 3) Independence; 4) Parable; 5) Inquiry; 6) Cooperation; and 7) Reinforcement. These seven components should be developed by the teacher so that the HME model based on the intermediate system can be implemented properly. Based on the explanation, the application of HME model based on the "among system" is one of the alternatives to increase the character values in low-grade-elementary-school students.

\section{METHODS}

This research used quantitative approach in the form of quasi experimental design. The study design was the 
randomized pretest-posttest only control group design. Population in this research was class III Primary School. The samples of this study were 2 classes consisting of experimental class and control class. Samples were taken randomly after passing random sampling criteria.

Data analysis for character values was done by using statistical test that was by comparing the questionnaire score after the implementation of HME model based on the "among system". The significant change between the experimental group and the control group was seen by looking at the achieved score. To see the description whether the character value increase between before and after implementing the model in general, the the normality test was done first before testing the hypothesis. The normality test formula was as below.

\section{Normalized Gain $(\mathrm{g})=($ Posttest Score-Pretest Score $) /$ (Maximum Score-Pretest Score)}

The hypotheses in this study were: 1) the character values that grew after implementing HME model based on "among system" in lower-grade-elementary students were better than before the implementation of HME model based on "among system" in low grade elementary students. 2) the character value of students taught by HME model based on the "among system" in lower-grade-elementary students was better than the value of student characters taught through conventional learning models.

\section{RESULT}

This research was part of researchs applying HME model development based on "among system" on the-low-gradeelementary students [17], [18]. This study discussed about the influence of HME model based on the "among system" on the character values of low-grade students.

\section{A. First Hypothesis}

Prior to statistical testing for the hypothesis, firstly the requirements analysis testing of the data in the form of questionnaire results of student character values was carried out. Based on the result of requirements analysis testing, it was obtained that the data was not normally distributed, so the hypothesis testing was conducted using non-parametric testing.

TABLE I. NON-PARAMETRIC TESTING RESULT

\begin{tabular}{|c|c|c|c|c|}
\hline \multicolumn{5}{|c|}{ Ranks } \\
\hline & & $\mathrm{N}$ & $\begin{array}{l}\text { Mean } \\
\text { Rank }\end{array}$ & Sum of Ranks \\
\hline & $\begin{array}{c}\text { Negative } \\
\text { Ranks }\end{array}$ & $0^{\mathrm{a}}$ & .00 & .00 \\
\hline $\begin{array}{l}\text { POST TEST } \\
\text { - PRE TEST }\end{array}$ & $\begin{array}{l}\text { Positive } \\
\text { Ranks }\end{array}$ & $21^{\mathrm{b}}$ & 11.00 & 231.00 \\
\hline & Ties & $0^{\mathrm{c}}$ & & \\
\hline & Total & 21 & & \\
\hline \multicolumn{5}{|c|}{ a. POST TEST < PRE TEST } \\
\hline \multicolumn{5}{|c|}{ b. POST TEST > PRE TEST } \\
\hline \multicolumn{5}{|c|}{ c. POST TEST = PRE TEST } \\
\hline \multicolumn{5}{|c|}{ Test Statistics ${ }^{\mathbf{a}}$} \\
\hline & & \multicolumn{3}{|c|}{ POST TEST - PRE TEST } \\
\hline \multicolumn{2}{|c|}{$\mathrm{Z}$} & \multicolumn{3}{|c|}{$-4.019^{b}$} \\
\hline \multicolumn{2}{|c|}{ Asymp. Sig. (2-tailed) } & \multicolumn{3}{|c|}{.000} \\
\hline \multicolumn{5}{|c|}{ a. Wilcoxon Signed Ranks Test } \\
\hline \multicolumn{5}{|c|}{ b. Based on negative ranks. } \\
\hline
\end{tabular}

The results of its output can be interpreted as follows.

\section{First Output "Ranks"}

- Negative Ranks or difference between the values of the character for pretest and posttest was 0 , either on the $\mathrm{N}$ value, Mean Rank, or Sum Rank. This value 0 indicated no decrease from the pretest value to the posttest value.

- Positive Range or difference between character values for pre test and post test. Here there are 21 positive data (N) which meant that 21 students had the increased motivation from pre test value to post test value. Mean Rank or average increased was 11.00 while the number of positive rank or sum of ranks was 231.00.

- Ties were the similarity of pretest and posttest values. Here the value of Ties was 0 , so it can be said that there was no equal value between pretest and posttest.

Second Output "Test Statistics"

Based on the above "Test Statistics" output, it was known that Asymp.Sig. (2-tailed) was worth 0.000, which was less than 0.05 . Hence it can be concluded that $\mathrm{H}_{0}$ was rejected. Thus, there was an increase in the character values of students between before and after being treated, so it can be concluded that there is influence of HME model based on the system among on the values of low-gradeelementary students.

\section{B. Second Hypothesis}

Testing the second hypothesis was done by comparing the gain score between the experimental class and the control class. Based on the normalized gain $(\mathrm{g})$, the result was $\mathrm{g}=$ 0.29 , so it can be categorized to be in low criteria.

TABLE II. GROUP STATISTICS

\begin{tabular}{|l|l|l|l|l|l|}
\hline & Group & $\mathrm{N}$ & Mean & $\begin{array}{l}\text { Std. } \\
\text { Deviation }\end{array}$ & $\begin{array}{l}\text { Std. } \\
\text { Error } \\
\text { Mean }\end{array}$ \\
\hline \multirow{2}{*}{ Gain } & Eksperimen & 21 & 6.95 & 1.717 & .375 \\
\cline { 2 - 6 } & Kontrol & 21 & 3.48 & 1.470 & .321 \\
\hline
\end{tabular}

\section{CONCLUSION AND Discussion}

Based on the results of the hypothesis testing, it can be concluded that the character value of students after being treated was better than that before being treated, and the value of student's character in the experimental class was better than the value of the student's character in the control class by looking at the gain of the score. Thus, the HME model based "among system" was one effective model for developing the character values of low-grade student compared to conventional models. This was because the HME model based "among system" engaged students to involve actively in learning, for example in the discussion stage by utilizing the surrounding environment, group and individual demonstrations. Other research results also suggested that active student's involvement as well as real experience can develop their character values [13].

Students' book as a support system also became one of the factors that can develop the character values of students, because in student's book there were interesting illustrations and mathematical problems that match with student's real 
life. As the character values were incorporated in the given mathematical problems, they were developed. The Figure 1 was an example of a problem in student's book.

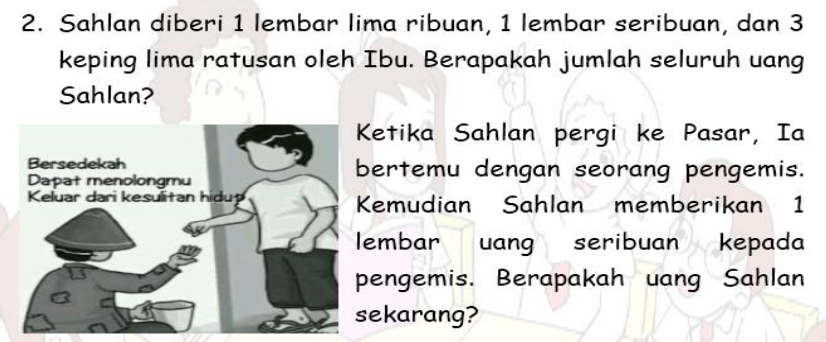

Fig 1. One example of mathematical problems in students' books

In Figure 1, it can be seen that the problems given can develop mutual respect, and love to help others. With the existence of such mathematical problems, it will make the students able to interpret the content of the lesson well, and then the spiritual potential of students will be developed as well.

Based on the results of the research, illustration was a very important aspect in students 'books, because it can increase students' understanding of the content being learned [34]. Without illustration, the excessive amount of material made learning less efficient [35]. Even when the text can be understood without pictures, images can support one's understanding in many ways [36]. Other studies also explain that in order to create meaningful and easily understood learning conditions, words and images were needed to be presented simultaneously [37]. Thus, the illustrations described in the student's book can develop the value the character values of students because the illustrations described in the student's book contained elements of character.

In this model, through the concept of "among system", the teacher as a guardian did not only let the students understand the material in the student's book, but the teacher also guided and directed the students if there were problems that were difficult to be understood in that book. For example, while conducting the discussion, the teacher also guided and directed students in solving problems in accordance with students' understanding to avoid mistakes in the concept. With the freedom given to students in solving the given problems as the concept of the "among system", more dared the students to express opinions and were responsible for what has been done.

In the HME model based on the "among system", students had the opportunity to discuss, express opinions, presented their work individually or in groups, and solved mathematical problems according to their wishes as long as they were in accordance with the concept, so that they can develop all potentials of the students as the concept of system among. Bloom (in Gulo, 2004) explained that a students were said to have understood and understood, if the student can explain a concept in his own words, can compare, distinguish, and can contrast the concept with another concept. In addition, through this model the teacher as a guardian guided and directed the students according to their own nature. Teachers as guardians also guided and directed them in an effort to foster positive characters in students through a positive language. The examples of the characters were honest, meticulous, cooperative, confident, consistent, and peace loving.

Based on the exposure, the HME Model based on "among system" on the-lower-grade-elementary students can indirectly develop students' characters values, as well as change the math learning atmosphere to be interesting and fun. As HME did not only develop students' potentials thoroughly, but also gave freedom and independence to the students to solve the problems given in mathematics. This model used the educational concept of $\mathrm{Ki}$ Hadjar Dewantara, ing ngarso sung tulodo, ing madyo mangun karso, tut wuri handayani. Ing ngarso sung tulodo meant that the teacher, in front of the class, gave an example. A teacher was an example for his students by giving examples of good habits that will shape the character of his students. Ing madyo mangun karso meant that the teacher was in the middle to build creativity. Then tut wuri handayani meant that the teacher was behind to give support.

Teachers must be able to provide motivation support to their students, because without the motivation, the students will be lazy to learn and not even understand the purpose of the learning. Teachers were the important element in learning, because teacher's performance also affected student's achievement [38], as described earlier. Therefore, teachers' creativity in order to make mathematics learning become meaningful and fun for students at the beginning of school was very important. In this model, the role of parents was also very important because by involving parents in learning will make students more motivated to learn.

From the above description, it was clear that this model made learning more interesting and meaningful for the students, so that it will bring the positive impact on the formation of the character values of the students not only develop all students' potential. Teachers also played an active role in guiding and directing students in accordance with the "among system" concept. Based on the "among system", learning will be more meaningful for the students, because the concept of the "among system" educated children by giving independence to them, keep children away from the pressing and compulsive learning methods, and inculcate the freedom that was very important to make the students more courageous in learning [26].

Some studies also explain that holistic education can make learning effective, and help students having diversity to be successful [24], [11]. Through the model's book, teacher's manual, and student's book that were the model of the support system, it was expected to facilitate teachers and students in applying HME model based on "among system" on low-grade students. Hence, mathematics learning became meaningful for the students.

\section{ACKNOWLEDGMENT}

The completion of the study must not be separated from the support of various parties. Therefore, the authors would like to thank:

- Strengthening the Directorate General Research and Development of the Ministry of Research, Technology and Higher Education of the Republic of Indonesia who have given doctoral dissertation research grants to researchers 
- Prof. Dr. Ahmad Fauzan, M.Pd, M.Sc as Promoter 1, Mrs. Prof. Dr. Mega Iswari, M. Pd as Promoter 2, and Mr. Afriva Khaidir, SH, M. Hum, Ph.D as Promoter 3 which has provided direction and guidance in the completion of this study

- Various parties that cannot be mentioned one by on

\section{REFERENCES}

[1] Rohana, "Peran Pendidikan Matematika Sebagai Wahana," in Seminar Nasional Matematika dan Pendidikan Matematika FMIPA UNY, 2012, no. November, pp. 978-979.

[2] A. Khaidir, Pendidikan Karakter (Sebuah Refleksi Pendekatan dalam Ilmu Sains. Padang: Sukabina Press, 2012.

[3] R. Soedjadi, "Kiat pendidikan matematika di Indonesia konstatasi keadaan masa kini menuju harapan masa depan," Direktorat Jenderal Pendidik. Tinggi, p. 325, 2000.

[4] J. S. Benninga, M. W. Berkowitz, and P. Kuehn, "the Relationship of Character Education Implementation and Academic Achievement in Elementary Schools," J. Character Educ., vol. 1, no. 1, pp. 19-32, 2003.

[5] M. George, "Ethics and Motivation in Remedial Mathematics Education," 84 Community Coll. Rev., vol. 38, no. 1, pp. 82-92, 2010.

[6] R. E. Mayer, "Cognitive , metacognitive , and motivational aspects of problem solving," Instr. Sci., vol. 26, no. 1-2, pp. 4963, 1998.

[7] M. A. Muñoz and J. E. Vanderhaar, "Literacy-embedded character education in a large urban district: effects of the child development project on elementary school students and teacher," J. Res. Character Educ., vol. 4, no. 1 \& 2, pp. 47-64, 2006.

[8] M. Watson, "Long-Term Effects of Moral/Character Education in Elementary School," J. Res. Character Educ., vol. 4, no. 1-2, pp. 1-18, 2006.

[9] A. S. Bryk, V. E. Lee, P. B. Holland, and A. S. Bryk, Catholic Schools and the Common Good. Cambridge: Harvard University Press, 2009.

[10] A. Bryk and B. Schneider, Trust in Schools: A Core Resource for Improvement. Russell Sage Foundation, 2002.

[11] T. Lovat, N. Clement, K. Dally, and R. Toomey, "Values education as holistic development for all sectors: Researching for effective pedagogy," Oxford Rev. Educ., vol. 36, no. 6, pp. 713729, 2010

[12] F. M. Newmann, Authentic achievement: restructuring schools for intellectual quality. San Francisco: Jossey-Bass Publishers, 1996.

[13] D. D. Williams, S. C. Yanchar, L. C. Jensen, and C. Lewis, "Character education in a public high school: A multi-year inquiry into unified studies," J. Moral Educ., vol. 32, no. 1, pp. 3-33, 2003.

[14] A. Bautista, S.-C. Ng, D. Múñez, and R. Bull, "Learning areas for holistic education: kindergarten teachers' curriculum priorities, professional development needs, and beliefs," Int. J. Child Care Educ. Policy, vol. 10, no. 1, p. 8, 2016.

[15] R. K. Sembiring, "PENDIDIKAN MATEMATIKA REALISTIK INDONESIA (PMRI): PERKEMBANGAN dan TANTANGANNYA," J. Math. Educ., vol. 1, no. 1, pp. 11-16, 2010.

[16] B. R. Joyce, M. Weil, and E. Calhoun, Models of Teaching. Pearson, 2011.

[17] R. Hayati, A. Fauzan, M. Iswari, and A. Khaidir, "The Validity of Holistic Mathematics Education Model Based Among System in The Low Grade Elementary School," in International Conference on Indonesian Islam, Education and Science (ICIIES), 2017, p. 717.
[18] R. Hayati, A. Fauzan, M. Iswari, and A. Khaidir, "Designing of Holistic Mathematic Education Model Based- ' System Among, at Low Grade Elementary Designing of Holistic Mathematic Education Model Based- ' System Among ' at Low Grade Elementary School," in IOP Conf. Series: Materials Science and Engineering, 2018.

[19] M. Latifah and N. Hernawati, "Dampak Pendidikan Holistik pada Pembentukan Karakter dan Kecerdasan Majemuk Anak Usia Prasekolah,” Jur. Ilm. Kel. Dan Kons, pp. 32-40, 2009.

[20] J. P. Miller, "Holistic Education in Japan: A Gaijan's (foreigner's) Journey," Encounter, no. 19, pp. 28-31, 2006.

[21] J. Musfah, Pendidikan Holistik: Pendekatan Lintas perspektif. Kencana, 2012.

[22] N. Rubiyanto and D. Haryanto, Strategi Pembelajaran Holistik di Sekolah. Jakarta: Prestasi Pustaka, 2010.

[23] L. T. Rudge, "Holistic Education: An Analysis of ITS Pedagogical Application," in Dissertation, 2008.

[24] L. E. Bernold, W. L. Bingham, P. H. McDonald, and T. M. Attia, "Impact of holistic and learning-oriented teaching on academic success," J. Eng. Educ., vol. 89, no. April, pp. 191-199, 2000.

[25] K. H. Dewantara, Karya Ki Hadjar Dewantara bagian pertama pendidikan. Yogyakarta: Majelis Luhur Persatuan Taman Siswa, 1977.

[26] F. Firdiansah and A. Suprijono, "Pendekatan Sistem Among Pada Proses Pembelajaran di SMK Taman Siswa Kediri Tahun 2006 2013/2013 Dalam Dinamika Modernisasi," Avatara, e-Journal Pendidik. Sej., vol. 1, no. 3, pp. 607-614, 2013.

[27] M. S. Reksohadiprojo, Masalah Pendidikan Nasional beberapa sumbangan pemikiran. Jakarta: CV Haji Masagung, 1989.

[28] K. Määttä and S. Uusiautti, "How do the Finnish family policy and early education system support the well-being, happiness, and success of families and children?," Early Child Dev. Care, vol. 182, no. 3-4, pp. 291-298, 2012.

[29] K. Määttä and S. Uusiautti, "Pedagogical love and good teacherhood," Educ., vol. 17, no. 1991, pp. 67-68, 2011.

[30] I. A. E. Putri, "Konsep pendidikan humanistik Ki Hajar Dewantara dalam pandangan Islam," in Sinopsis Tesis, Semarang: IAIN Walisongo, 2012.

[31] M. N. Wangid, "Sistem Among Pada Masa Kini : Kajian Konsep Dan Praktik Pendidikan," J. Kependidikan, vol. 39 No. 2, no. November, pp. 129-140, 2009.

[32] S. Wiryopranoto, N. Herlina, D. Marihandono, and Y. B. Tangkiisan, Ki hajar dewantara "Pemikiran dan Perjuangannya," Djoko Mari. Museum Kebangkitan Nasional Direktorat Jendral Kubudayaan Kementrian Pendidikan dan Kebudayaan, 2017.

[33] A. Hurwitz and M. Day, Children and Their Art: Methods for the Elementary School. 2007.

[34] A. Basal, K. M. Celen, H. Kaya, and Ş. N. Boğaz, "An investigation into illustrations in English course books in a Turkish context," Int. Electron. J. Elem. Educ., vol. 8, no. 3, pp. 525-536, 2016.

[35] A. Kuzu, "Application of Multimedia Design Principles To Visuals Used in Course-Books: an Evaluation Tool," Turkish Online J. Educ. Technol. - TOJET April, vol. 6, no. 2, pp. 13036521, 2007.

[36] S. Molitor, S.-P. Ballstaedt, and H. Mandl, "Problems in Knowledge Acquisition from Text and Pictures," Knowledge Acquisition from Text and Pictures, vol. 58. pp. 3-35, 1989.

[37] İ. Çakir, "Instructional materials commonly employed by foreign language teachers at elementary schools," Int. Electron. J. Elem. Educ., vol. 8, no. 1, pp. 537-550, 2015.

[38] İ. Sanberk and S. Bağiş, "How do third-grade students and their teachers construe each other?," Int. Electron. J. Elem. Educ., vol. 8, no. 4, pp. 559-572, 2016. 